Papers and Proceedings of the Royal Society of Tasmania, Vo1.109, 1975

(ms. received 8.5 .1975 )

\title{
THE LATE CAMBRIAN TO EARLY ORDOVICIAN SEQUENCE

\author{
ON THE DENISON RANGE, SOUTHWEST TASMANIA
}

by K.D. Corbett

Department of Mines, Hobart

(with three text-figures)

\section{ABSTRACT}

A well-exposed middle Late Cambrian to Early Ordovician clastic sequence, herein referred to as the Denison Subgroup, unconformably overlies Middle Cambrian rocks on the Denison Range and is conformably overlain by Ordovician limestone. Four formations are recognized. The basal Singing Creek Formation $(720 \mathrm{~m})$ consists of interbedded siltstone, quartzwacke turbidites, siliceous fine conglomerate, and slump sheets, and contains an abundant Franconian trilobitembrachiopod fauna. It grades upwards into the Great Dome Sandstone $(510 \mathrm{~m})$, a shallow marine-deltaic-fluvial sequence of crossbedded quartz sandstone, siltstone and fine conglomerate, with a sparse fauna of probable Late Cambrian age. Above this the Reeds Conglomerate (1560 $\mathrm{m})$ comprises largely non-marine pink siliceous conglomerate and cross-bedded sandstone, probably deposited on alluvial fans. This grades into the marine Squirrel Creek Formation, comprising a lower sandstone member $(150 \mathrm{~m})$ with worm burrows and gastropods, a siltstone-1imestone member $(150 \mathrm{~m})$ with an abundant Early Ordovician shelly fauna, and an upper sandstone member $(300 \mathrm{~m})$.

The Denison Subgroup is approximately equivalent to the pre-limestone part of the Junee Group in the original area of Lewis, and to the Owen Conglomerate of western Tasmania.

\section{INTRODUCTION}

The Denison Range lies some 20 kilometres north of the old mining township of Adamsfield and some 35 kilometres northwest of Maydena, in southwest Tasmania. The area was mapped by the author during 1966-68 as part of a Ph.D. study at the University of Tasmania. Access to the area is possible only by foot or by helicopter, and most of the field work was carried out from a helicopter-supplied camp at Lake Rhona in conjunction with a mineral exploration programme then being conducted by the Broken Hill Proprietary Co. Ltd. Financial assistance was provided by a B.H.P. Postgraduate Scho1arship in Geology.

Research was concentrated on the previously unknown Late Cambrian flysch-paralic sequence, and some details of the sedimentology of that sequence have already been published (Corbett 1972, 1973). A general outline of the geology of the area was given in Corbett and Banks (1974), together with details of the Ordovician stratigraphy and palaeontology in adjacent areas. The reader is referred to that paper for the geological setting of the Denison Range sequence. More recently, the Geological Survey of Tasmania has been mapping the areas west and south of the Denison Range, and considerable new information on that area will shortly be available. The only early reference of note on the Denison Range is that of Twelvetrees (1908), who noted the "Cambrian" conglomerates on the main part of the range, with underlying quartzite and overlying limestones, in his exploration of the Great Western Railway route (see summary by Ward 1910).

In an earlier paper (Corbett and Banks 1974) the Reeds Conglomerate was included 
in a re-definition of the Junee Group, since it was regarded as a correlate of the Tim Shea Sandstone in the area of Lewis's (1940) original "Junee Series". However, this correlation has been questioned by Brown et al (this volume), who argue that the Junee Group should only be defined in Lewis's original area and that correlations to other areas should not be involved. The problem of Junee Group teminology is discussed in a separate paper (Corbett and Banks, this volume), but the Reeds Conglomerate is now included in the Denison Subgroup, which may be regarded as approximately equivalent to the pre-limestone part of the Junee Group.

The stratigraphic succession in the Denison Range area may be summarized as follows (thicknesses estimated): Limestone of Gordon Subgroup ( Squirrel Creek Formation (Early Ordovician) $700 \mathrm{~m}+$ ( Reeds Conglomerate

Denison

$\begin{array}{ll}\text { Subgroup } & \text { (Great Dome Sandstone. (Late Cambrian ?) } \\ & \text { (Singing Creek Formation (Franconian) }\end{array}$ $600 \mathrm{~m}$ $1560 \mathrm{~m}$ ( Singing Creek Formation (Franconian)

Unconformity Probable unconformity Tria1 Ridge Beds (Middle Cambrian) Pyritic phyllite or schist (Precambrian)

\section{TRIAL RIDGE BEDS}

These comprise a sequence of siliceous conglomerate, sandstone and siltstone exposed on Trial Ridge, just west of the Denison Range (fig. 1). The sequence dips fairly uniformly ESE at about $60^{\circ}$ over most of the ridge. The beds are truncated by the overlying Singing Creek Formation at the northern end of Trial Ridge, the unconformity being exposed at about E42312, N76167. Here there is an angular discordance in strike of about $20^{\circ}$, the underlying sandstone beds dipping ESE at about $60^{\circ}$, and the overlying basal conglomerate dipping east at about $53^{\circ}$.

Further north, in Kindling Creek, the lower conglomerate of the Trial Ridge Beds overlies a crenulated black pyritic phyllite or quartz-schist, and the contact, although not exposed, is thought to be an unconformity. The rock resembles the crenulated phylitic rocks which occur within Precambrian sequences elsewhere.

The sequence has a maximum thickness of at 1 east 500 metres, and consists largely of siliceous conglomerate and cross-bedded quartz sandstone in the lower part and of interbedded lithic-quartz wacke and siltstone, with lesser siliceous conglomerate, in the upper part. Some of the sandstone beds in the upper part show graded bedding and erosional sole marks, and may be turbidites.

Fossils have recently been discovered in the Trial Ridge Beds by members of the Geological Survey of Tasmania, and a Middle Cambrian age has been assigned to them (A.V. Brown and N.J. Turner, pers. comm.).

\section{DENISON SUBGROUP}

The Denison Subgroup is defined as comprising the Singing Creek Formation, Great Dome Sandstone, Reeds Conglomerate, and Squirrel Creek Formation, as defined below. It has a total thickness of about 3390 metres, and ranges in age from middle late Cambrian to Early Ordovician. The bulk of the sequence comprises a Late Cambrian regression from marine proximal flysch facies through shallow marine, deltaic and fluvial sandstones to non-marine fanglomerate, while the upper part represents an Early Ordovician transgression. Virtually all the clastic material is of Precambrian origin, and the current direction data indicate derivation from the Tyennan Nucleus just to the west. 
K.D. Corbett

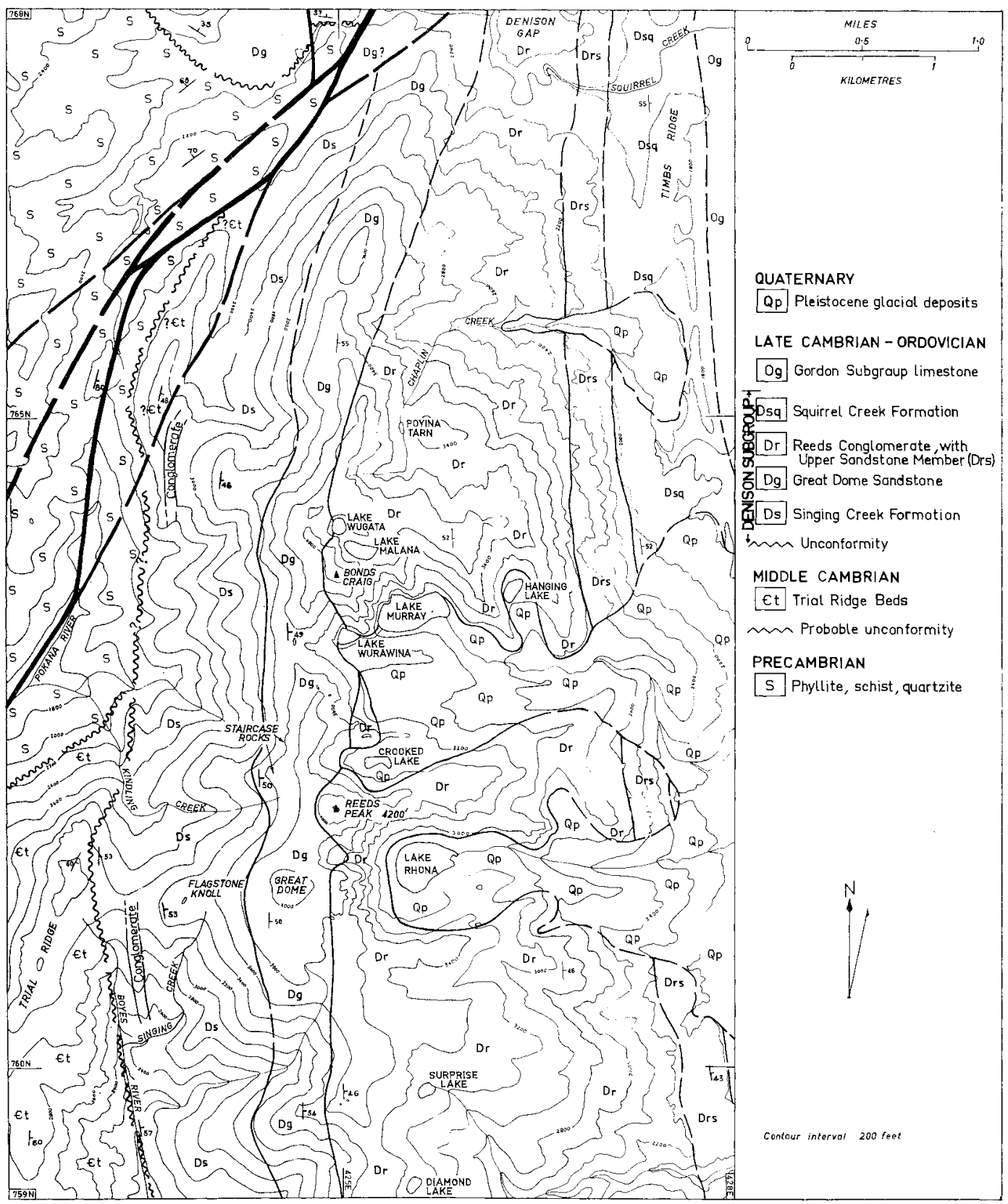

FIG. 1. - Geology of the centra1 and northern parts of the Denison Range (after Corbett 1970). 
The Denison Range area was apparently the deepest part of the Late Cambrian basin, and the lower marine formations wedge out progressively to the north and to the south and east. The Singing Creek Formation is apparently not represented at Tim Shea, in the type area of Lewis's original "Junee Series", and further east towards Maydena the base of the section comprises pebbly sandstone of probable Early Ordovician age (M.R. Banks, pers. comm.). The basal unconformity on the Denison Range, however, appears to be the same as that forming the base of the "Junee Series" in the Tim Shea area (see Corbett and Banks, this volume). Thus the Denison Subgroup may be considered as representing the expanded and more complete section between the Gordon Subgroup limestones and the basal unconformity of the Junee Group. It corresponds to the "Denison Range conglomerates and quartzites" of Ward (1910, p. 127).

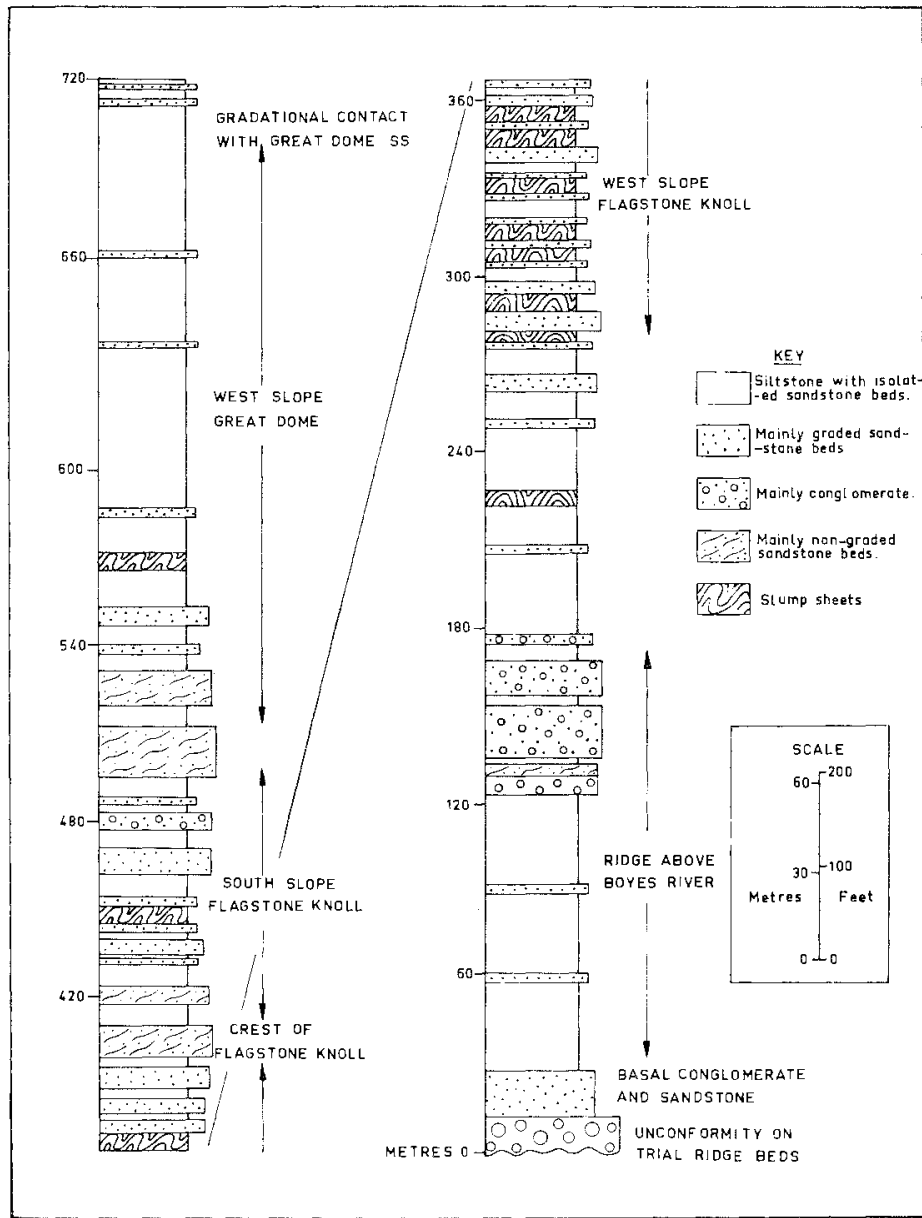

FIG. 2. - Composite section of Singing Creek Formation.

\section{SING ING CREEK FORMATION}

This comprises some 720 metres of interbedded quartzwacke sandstone, laminated micaceous siltstone, siliceous conglomerate and slump sheets. The base is the unconformity on the Trial Ridge Beds, and the top is a conformable gradation into Great Dome Sandstone exposed at Staircase Rocks (fig. 1). The sequence dips uniformly east at $45^{\circ}-55^{\circ}$ and is apparently free of tectonic cleavage.

No single complete type section is available. A composite but partly diagrammatic section (fig. 2) has been compiled from exposures near Trial Ridge, in Singing Creek, on Flagstone Knol1, on the west flank of Great Dome and at Staircase Rocks. Fawn-weathering grey laminated siltstone and silty fine sandstone forms the basis of the formation and occurs as more or "less pure sequences at the top and near the base. Pale grey, white-weathering quartzwacke sandstone occurs as single beds and as composite units up to 25 metres thick. Granule to cobble grade silic eous conglomerate beds occur sporadically through the sequence, and form a basal unit and another on a small ridge just east of the upper Boyes River. Slump sheets, including pebbly mudstones, up to several metres thick, are abundant in parts of the section (Corbett 1973). 


\section{K.D. Corbett}

Depositiona 1 environment:- Many of the thinner sandstone beds (up to $30 \mathrm{~cm}$ ) show grading, and nearly all have sharp bases. Sole marks are common, and include longitudinal ridges, obstacle scours, tool marks, flute marks, channels and load marks. Many beds show a sequence of internal structures from a basal structureless division followed by a division of parallel lamination, a division of cross-lamination, and an upper division of laminated siltstone. The features correspond to those of classical turbidites as described by Bouma (1962). There are also thicker (up to $2 \mathrm{~m}$ ) nongraded sandstone beds, some of which show dish structures, wavey lamination and elutriation columns. These rocks have been described previously (Corbett 1972) and interpreted as also being turbidity current deposits.

The composite sandstone and sandstone-conglomerate sequences are interpreted as being channel deposits, at least in part, and the formation as a whole is thought to represent a submarine fan complex (Corbett 1970). Measurement of 67 flutes and parting lineations indicates currents from the west, and this together with other provenance indicators, particularly the abundance of Precambrian detritus, indicates derivation from the Tyennan Nucleus.

Palaeontology:- Siltstone and fine sandstone beds in the lower, middle and upper parts of the formation contain a marine fauna of trilobites, articulate and inarticulate brachiopods, rare gastropods, and numerous trace fossils. The most common trilobites are Proceratopyge sp. and Pseudagnostus sp., and the fauna includes several new agnostid species and genera, and a form 1 ike sigmocheizus sp. (J.B. Jago, pers. comm.) . Articulate brachiopods include Bizlingselta cf cormgata, Bilzingselza sp. nov., and a form like Jamese $27 \alpha \mathrm{sp}$. , and the inarticulates include Lingulezla cf perattenuata, a form like Pseudodiceliomus sp., and a form like Palaeobolus sp. (M.R. Banks, pers. comm.). Banks suggests a lower Franconian age (probably Elvinia Zone), and Jago suggests an kilvinia zone or Conaspis Zone age.

Correlates of the Singing Creek Fomnation:- A correlate on the west flank of the Stepped Hills includes siltstone, quartzwacke sandstone and siliceous fine conglomerate. Trilobites, inarticulate and articulate brachiopods (including Bizlingsezza sp.), gastropods, bivalves and trace fossils occur in these beds. At Adamsfield, a sequence of serpentinitic conglomerate, calcareous sandstone, siltstone and impure limestone, which unconformably overlies the Adamsfield ultramafic body (Corbett 1970), contains an abundant marine fauna of Late Cambrian age (Upper Dresbachian-Lower Franconian, Opik, in Banks 1962) and may be equivalent to the Singing Creek Formation. There is no apparent correlate of the formation on the Ragged Range. To the north, the formation apparently wedges out against a major fault zone between the Denison Range and Battlement Hills, and is not present west of this fault.

In western Tasmania, a correlate occurs in the Tyndall Range area, where a marine sequence of siltstone, quartzwacke sandstone, and siliceous conglomerate forms the lower part of the Owen Conglomerate correlate (Corbett in press). This sequence is sedimentologically similar to the Singing Creek Formation, and contains a middle Late Cambrian trilobite fauna with major el ements in common with the Singing Creek fauna (particularly Proceratopyge sp. and Pseudagnostus sp.). The fauna is probably of Franconian age (J.B. Jago, pers. comm.).

\section{Great Dome Sandstone}

This comprises some 510 metres of grey quartzose sandstone, conglomeratic sandstone, fine conglomerate and micaceous siltstone exposed on the west flank of the Denison Range between Staircase Rocks and Reeds Peak (fig. 1). The base at Staircase Rocks (E42429, N76226) is transitional downwards through some ten metres of interbedded sandstone and siltstone to siltstone of the Singing Creek Formation. The top is exposed in the ravine about 150 metres south of Reeds Peak, and is marked by a transition from grey conglomeratic sandstone to pink siliceous conglomerate. A gastropod from the lower part of the formation has been tentatively identified as Kobayashiezza sp. by Mr. M.R. Banks (pers. comm.), suggesting a Late Cambrian age. 


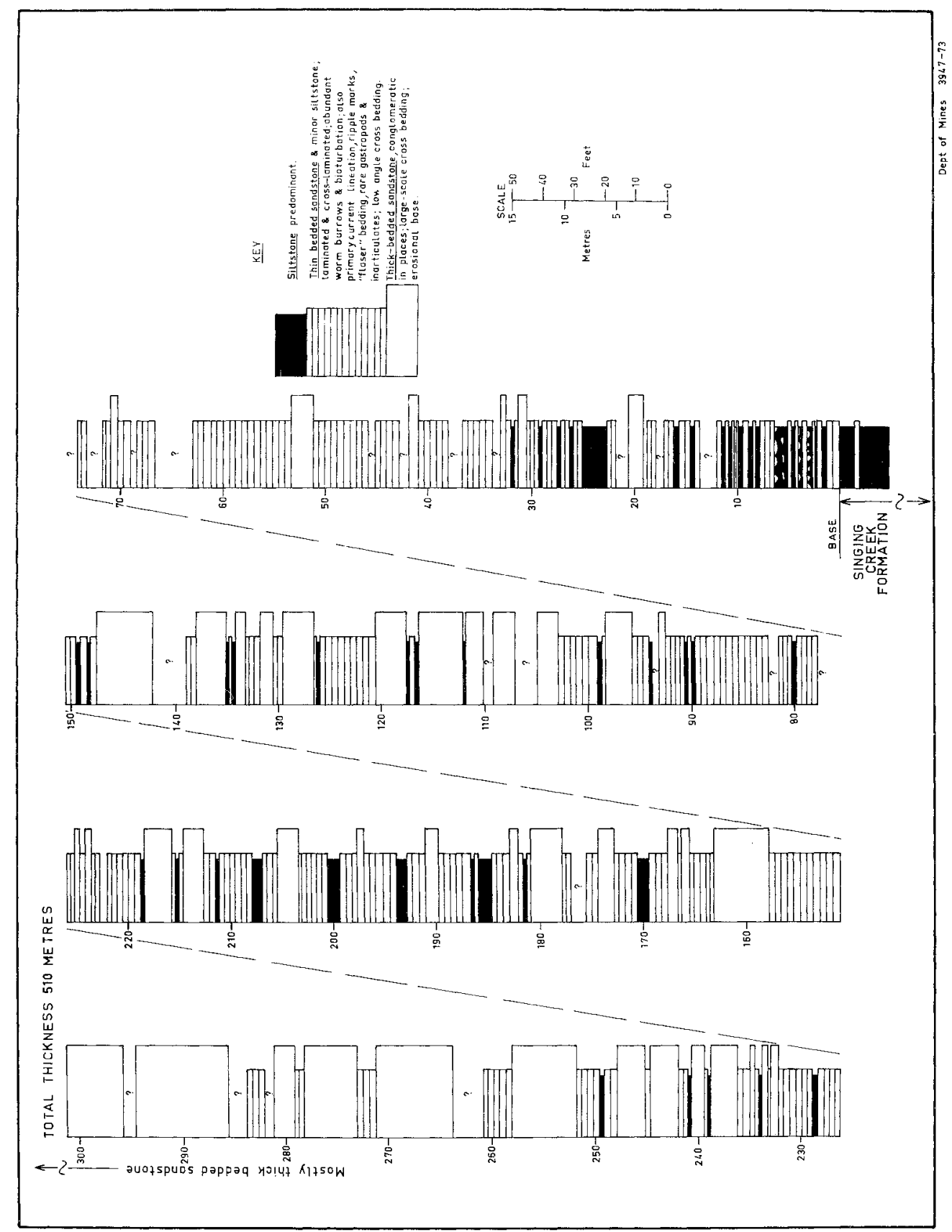

FIG. 3. - Section through lower part ("cyclic facies") of Great Dome Sandstone, Staircase Rocks area. 


\section{K.D. Corbett}

The lower 250 metres or so of the formation shows a characteristic alternation of white coarse sandstone units, up to six metres thick, and thin-bedded sandstonesiltstone units up to 15 metres thick (fig. 3). The coarse units crop out strongly to form a series of parallel steps or ridges, and typically show 1arge-scale trough cross-bedding and have channelled bases. They are interpreted as meandering distributary channel and tidal channel deposits (Corbett 1970).

The thin-bedded zones, which may include dark micaceous siltstone units up to 1.5 metres thick, show a variety of sedimentary structures including cross-bedding and cross-lamination of several kinds, low-angle (beach-type) cross-bedding, ripple marks, flat lamination with parting lineation, current crescents, large and smal1 pseudonodules, channel structures and deformed lamination. Bioturbation is common, some beds up to a metre thick having been completely reworked. Trace fossils are abundant, particularly vertical and U-shaped burrows. Rare gastropods and small inarticulate brachiopods occur at some horizons. A vertical sequence of 1 ithofacies can be demonstrated in some of the thin-bedded zones, and the interpreted environments include low and high tidal flats, lagoons, barrier beaches and surf zones. The cyclic sequence as a whole appears to represent a complex, tidally-influenced delta-platform deposit (Corbett 1970).

The upper half of the formation consists mainly of grey, cross-bedded quartzose coarse sandstone, conglomeratic sandstone and fine conglomerate, with only thin intercalations of thin-bedded sandstone-siltstone and bioturbated sandstone. This section is interpreted as a delta floodplain deposit with minor marine influence. Most of the upper half of the formation is red in colour in the area west of Bonds Craig, but reverts to grey near the top.

Correlates of the Great Dome Sandstone:- A correlate in the Battlement Hills area overlies a coarse, locally-derived breccia which rests unconformably on Precambrian rocks (first noted by Twelvetrees 1908). The sequence here consists of cross-bedded quartzose sandstone with bioturbated flaggy sandstone. It has a maximum thickness of about 180 metres but thins rapidly to the northwest and is overlapped by conglomerate.

A correlate on Stepped Hills is about 300 metres thick, and comprises cross-bedded sandstone, flaggy sandstone, minor siltstone and minor glauconitic sandstone. A few inarticulate brachiopods and gastropods occur in this sequence. Similar rocks, with bioturbated sandstone beds, occur in the Gordon River at the northwest foot of C1ear Hill, and on the adjacent slopes of Clear Hill.

A correlate on the upper western slopes of the Ragged Range is some 180 metres thick, and comprises basal chert-rich conglomerate followed by interbedded quartzose sandstone, micaceous siltstone and haematitic siltstone. The sequence here is unconformable on older Cambrian chert, greywacke and mudstone (Corbett 1970). At Adamsfield, a correlate is exposed in two small reservoirs on Packers Ridge, and comprises a sequence of thin-bedded sandstone, siltstone and pebble conglomerate, with abundant worm burrows as well as gastropods, inarticulate brachiopods and very rare trilobites. Detrital chromite is common through the sequence.

Reeds Conglomerate

This has been previously defined by Corbett and Banks (1974) as "the formation of quartzose conglomerate and conglomeratic sandstone, usually red to purplish in colour, occurring on the crest and eastern slopes of the Denison Range. It has a maximum thickness of about 1560 metres........". The base may be taken as the change from grey. sandstone to pink conglomerate which occurs in the ravine 150 metres south of Reeds Peak. The top is formed by the Upper Sandstone Member. The age of the formation is not known, but as the overlying unit is Early ordovician and the underlying unit Late Cambrian, it probably spans the Cambrian-Ordovician boundary. 


\section{Late Cambrian to Early Ordovician Sequence, Denison Range}

The conglomerate sequence dips uniformly east at about $50^{\circ}$. Rapid variations from pebble conglomerate to conglomeratic sandstone and sandstone are typical, and there are larger-scale alternations of conglomerate-rich and sandstone-rich units. Clasts are typically well rounded, with moderate to high sphericity, and composed dominantly of either quartzite or quartz-schist. Maximum clast size is about $20 \mathrm{~cm}$ (cobbles), the majority being 1 ess than $10 \mathrm{~cm}$.

The Upper Sandstone Member (fig. 1) occurs along the lower eastern slopes of the range, and is a sequence of grey to pale pink quartzose sandstone, granule conglomerate and pebble conglomerate about 100 metres thick. Its base is transitional to relatively thick-bedded pebble conglomerate, and coincides with a flattening of the slope about 450 metres east of Hanging Lake. The contact with the overlying Squirrel Creek Formation is marked by the appearance of flat-bedded white sandstone with worm burrows on the lower dip slopes east of the above. Complex trough cross-bedding is prominent in most outcrops, and there is a tendency towards columnar weathering in the sandstone beds. A correlate of the member occurs in the Battlement Hills area, where it consists largely of granule to pebble conglomerate. To the south, a correlate of the Member forms the crest and eastern slopes of the Stepped Hills and appears also to be present on Mt. Wright, the east flank of Clear Hill, and along the Saw Back Range (Corbett 1970 ).

Depositional environment and palaeogeography:- Sedimentary structures in the Reeds Conglomerate include abundant channels and trough cross-bedding in the sandstone and fine conglomerate, and thick bedding with rare large channel structures and large-scale, heterogeneous cross-bedding in the coarser conglomerates. Imbrication of discoidal clasts is apparent in some outcrops. The sedimentary features suggest deposition largely by braided streams, probably on large alluvial fans (see Corbett and Banks 1974, for further discussion). Cross-bedding measurements indicate a westerly derivation, and the predominance of quartzite and quartz-schist clasts indicates that the Tyennan Nucleus was the main source area.

Correlates of the Reeds Conglomerate:- The formation can be traced from northwest of Battlement Hills through the Denison Range, Stepped Hills etc. to the Ragged Range and Saw Back Range in the south. The great thickness variations over this area are outlined in Corbett and Banks (1974). The formation was considered to be lateral1y equivalent to the Tim Shea Sandstone $(i b i d)$, which occurs to the southeast, but this is not provable and that formation may also include correlates of the Great Dome Sandstone, as suggested by Brown et al. (this volume).

The formation is only partially equivalent to the Owen Conglomerate of western Tasmania. That formation, as defined by Wade and Solomon (1958), includes fossiliferous sandstone of probable Early Ordovician age in the upper part, which is therefore a correlate of the Squirrel Creek Formation in this area. The base of the Owen Conglomerate, although unfossiliferous in most areas, contains middle Late Cambrian fossils in what is apparently a local marine facies near the Tyndall Range (Corbett in press), and this part of the formation is a correlate both lithologically and palaeontologically, with the Singing Creek Formation. Thus the Owen Formation is apparently equivalent to the entire Denison Subgroup from the basal unconformity to the base of the Gordon Subgroup.

\section{Squirre1 Creek Formation}

Conformably overlying the Upper Sandstone Member of the Reeds Conglomerate, and underlying the limestone sequence of the Vale of Rasselas, is a sequence of about 600 metres of fossiliferous marine sandstone, siltstone and impure limestone designated the Squirrel Creek Formation. A lower sandstone member, a siltstone-limestone member and an upper sandstone member are distinguished. The sequence can be correlated with the Florentine Valley Formation of the Tim Shea area (Corbett and Banks 1974), but is separated from that section by an area of poor exposure and superficial cover around the southern Vale of Rasselas. Further mapping may establish precise equivalence of 


\section{K.D. Corbett}

the two formations, in which case the new name can be dropped in favour of Florentine valley Formation. The sequence dips east at about $55^{\circ}$, and is best exposed in Squirrel Creek and south thereof.

The lower sandstone member is about 150 metres thick, and is best exposed on the lowermost dip slopes of the Denison Range between Hanging Lake and just north of Squirre1 Creek. It consists typically of flat-bedded and flaggy white siliceous sandstone, with lesser cross-bedded coarse sandstone, micaceous siltstone and glauconitic sandstone. Worm burrows and casts, and bioturbated zones, are common.

Gastropods occur in a few beds, and include a form close to Raphistoma sp., suggesting an Early Ordovician age (M.R. Banks, pers. comm.).

The siltstone-limestone member is about 150 metres thick, and forms a narrow valley at the foot of the range. In Squirrel Creek it consists of interbedded grey to yellow calcareous siltstone, fine sandstone, and impure nodular 1 imestone. It contains an abundant fauna of trilobites (including Asaphopsis juneensis), brachiopods and gastropods. The fauna is similar to that of the Florentine valley Formation at The Gap (Corbett and Banks 1974) and is Early Ordovician in age.

The upper sandstone member is about 300 metres thick, and forms a low ridge (Timbs Ridge) just east of the range. In Squirrel Creek it consists of grey, green and buff-coloured quartzose and micaceous sandstone with interbedded siltstone and glauconite bands. It contains a sparse fauna of brachiopods, trilobites and gastropods.

\section{GORDON SUBGROUP CORRELATE}

Limestone correlated with the Gordon Subgroup of Corbett and Banks (this volume) is poorly exposed in the Vale of Rasselas east of Timbs Ridge. The lower part of the sequence was examined in Squirrel Creek, where bars of impure stylolitic and nodular limestone are intermittently exposed over a stratigraphic interval of about 650 metres (assuming $50^{\circ} \mathrm{dip}$ ). Above this is a unit of white-weathering siliceous coarse sandstone, about 60 metres thick, which forms a narrow strike ridge in the centra1 part of the valley. The sandstone is cross-bedded in places, and contains traces of marine fossils and worm burrows. The limestone sequence above this was not examined.

A ridge of similar coarse siliceous sandstone occurs within the limestone sequence in the valley north of Battlement Hills (Corbett 1970).

\section{ACKNOWLEDGEMENTS}

The author acknowledges critical reading of the manuscript by Dr. E. Williams, Mr. A.V. Brown and Mr. N.J. Turner of the Geological Survey of Tasmania, and Mr. M.R. Banks of the Geology Department, University of Tasmania. The paper is published with permission of the Director of Mines, Tasmania.

\section{REFERENCES}

Banks, M.R., 1962: The Cambrian System in THE GEOLOGY OF TASMANIA (A.H. Spry and M.R. Banks Eds.). J. geol. Soc. Aust., 9 (2), 127-146.

Bouma, A.H., 1962: SEDJMENTOLOGY OF SOME FLYSCH DEPOSITS. A GRAPHIC APPROACH TO FACIES INTERPRETATION. Elsevier, Amsterdam, $168 \mathrm{pp}$.

Brown, A.V., Turner, N.J. and Williams, E., 1975: The basal beds of the Junee Group. Pap. Proc. Roy. Soc. Tasm., this volume, 107-110.

Corbett, K.D., 1970: Sedimentology of an Upper Cambrian flysch-paralic sequence (Denison Group) on the Denison Range, southwest Tasmania. Unpub. Ph. D. thesis, Univ. of Tasm. 
, 1972: Features of thick-bedded sandstones in a proximal flysch sequence, Upper Cambrian, southwest Tasmania. SedimentoZogy, 19 (1/2), 99-114.

, 1973: Open-cast slump sheets and their relationship to sandstone beds in an Upper Cambrian flysch sequence, Tasmania. J. Sediment. Petroz., 43 (1), 147-159.

in press: Preliminary report on the geology of the Red Hil1s-Newton Creek area, West Coast Range, Tasmania. Tech. Rep. Dep. Mines, Tasm., 19.

, and Banks, M.R., 1974: Ordovician stratigraphy of the Florentine Synclinorium, southwest Tasmania. Pap. Proc. Roy. Soc. Tasm., 107, 207-238.

Lewis, A.N., 1940: Geology of the Tyenna Valley. Pap. Proc. Roy. Soc. Tasm. (1939), $33-59$.

Twelvetrees, W.H., 1908: Tyenna to Ge11 River. Tasm. Parl. Pap., 13, $25-33$.

Wade, M.L., and Solomon, M., 1958: Geology of the Mt, Lyell mines, Tasmania. Econ. Geot., 53 (4), 367-416.

Ward, L.K., 1910: Contribution to the geology of Tasmania. The Precambrian. Pap. Proc. Roy. Soc. Tasm. (1909), 124-157. 